\title{
THE STATE, PROBLEMS AND PROSPECTS OF CONTAINER SHIPBUILDING IN THE WORLD
}

\section{СТАН, ПРОБЛЕМИ ТА ПЕРСПЕКТИВИ КОНТЕЙНЕРНОГО СУДНОБУДУВАННЯ У СВІТІ}

\author{
Olha I. Petrenko \\ olga_co@meta.ua, olga.petrenko. \\ bltt.duit@gmail.com \\ ORCID: 0000-0002-1869-7999
}

\section{О. І. Петренко,} канд. екон. наук, доцент, завідувач кафедри бізнес-логістики та транспортних технологій

\section{State University of Infrastructure and Technologies, Kyiv Державний університет інфраструктури та технологій, м. Київ}

\begin{abstract}
Shipbuilding shapes the future of maritime transport. Development of world maritime trade, level of fleet renewal, economic efficiency, speed, safety, environmental friendliness of sea container transportation depends on the quality, volume, innovation of container shipbuilding. The purpose of the article is to investigate the status, dynamics, problems and prospects of container shipbuilding in the world, to determine the role of fleet renewal in the provision of container shipping and the development of global maritime trade. The methodological basis of the research is the informal content analysis and systematic synthesis of information obtained from foreign and domestic sources of information. In the field of container shipbuilding, current trends are taking into account market requirements and environmental legislation. The design and construction of large-capacity container vessels must meet the standards of safety, energy efficiency and environmental friendliness, better hydrodynamics. Important in the field of shipbuilding are the digitization of processes, the use of artificial intelligence, blockchain. There is an imbalance in the geographical location of shipbuilding facilities and the level of development of national economies, which affects the construction and operation of a container vessel fleet. Shipbuilding is undergoing reform, consolidation and evolving thanks to strong government support. Eco-friendliness and cost-effectiveness remain a constant benchmark in shipbuilding and incentives in the modernization of maritime transport. Scientific novelty. The problems of development of modern shipbuilding of new container vessels and the main tendencies in this sphere are investigated from international sites and foreign sources. Practical importance. The results of the study can be used in the shipbuilding industry, as well as by all interested parties involved in sea container transportation.
\end{abstract}

Key words: shipbuilding; container ships; world fleet; sea container transportation; maritime transport.

Анотація. Суднобудування формує майбутнє морського транспорту. Від якості обсягів, інноваційності суднобудування контейнерних суден залежить розвиток світової морської торгівлі, рівень оновлення флоту, економічна ефективність, швидкість, безпека, екологічність морських контейнерних перевезень. Метою статті є дослідження стану, динаміки, проблем та перспектив контейнерного суднобудування у світі, визначення ролі оновлення флоту в забезпеченні контейнерних перевезень та розвитку глобальної морської торгівлі. Методичну основу дослідження становлять неформалізований контент-аналіз та системне узагальнення відомостей, отриманих з іноземних та вітчизняних джерел інформації. У сфері контейнерного суднобудування сучасними тенденціями є врахування вимог ринку й екологічного законодавства. Проектування та будівництво контейнерних суден великої місткості має відповідати стандартам безпеки, енергозбереження та екологічності, кращої гідродинаміки. Актуальними в галузі суднобудування є цифровізація процесів, застосування штучного інтелекту, блокчейн. Проблемами останніх років у галузі контейнерного суднобудування залишається диспропорція між коливаннями світової торгівлі та пропозицією флоту, обсягами замовлень у суднобудуванні. Спостерігається дисбаланс за географічним розташуванням суднобудівних потужностей та рівнем розвитку національних економік, що впливає на будівництво й експлуатацію флоту контейнерних суден. Сфера суднобудування зазнає впливу реформ, консолідації та розвивається завдяки значній підтримці уряду. Екологічність та економічна ефективність залишаються незмінним орієнтиром у суднобудуванні та стимулами в процесах модернізації морського транспорту. Наукова новизна. Досліджено з міжнародних сайтів та іноземних джерел проблемні питання розвитку сучасного суднобудування нових контейнерних суден та основні тенденції в цій сфері. Практична значимість. Результати дослідження можуть бути використані в суднобудівній галузі, а також всіма зацікавленими сторонами, що беруть участь у морських контейнерних перевезеннях.

Ключові слова: суднобудування; контейнеровози; світовий флот; морські контейнерні перевезення; морський транспорт. 


\section{ПОСТАНОВКА ЗАДАЧІ}

За суднобудуванням - майбутнє морського транспорту, від якості та обсягів суднобудування контейнерних суден залежать розвиток світової морської торгівлі, якісне оновлення флоту, а відповідно економічність, екологічність та швидкість вантажних контейнерних перевезень.

Дослідження розподілу контейнерних суден за віком важливе для оцінки економічної та екологічної надійності цього виду морського транспорту. Вік флоту виступає вагомим фактором у прийнятті рішень щодо оновлення, модернізації чи утилізації складових частин флоту, суден, а це, своєю чергою, впливає на показники капітальних інвестицій, постачання потужностей, конкуренцію, розмір тарифів, фрахту і прибутку.

Контейнерні перевезення набирають дедалі більшої популярності через універсальність у застосуванні видів транспорту та придатності для різних вантажів. Крім того, розвитку контейнерних перевезень сприяє пожвавлення економіки, виробництва, електронної торгівлі, модернізація транспортної інфраструктури, новітнє суднобудування.

Суднобудування тісно пов'язане 3 потребами оновлення флоту, забезпечення його відповідності сучасним потребам, інноваціям у цій сфері, вимогам до безпеки та екологічності, що виступає важливим об'єктом для дослідження.

\section{АНАЛІЗ ОСТАННІХ ДОСЛІДЖЕНЬ І ПУБЛІКАЦІЙ}

Суднобудуванню у світі і в Україні приділяється значна увага в науковій літературі. Проблеми та перспективи суднобудівної галузі України у глобальному контексті висвітлюються у праці В.О. Діордієва [1]. Тенденції, обсяги, лідери ринку суднобудування розкрито в публікації В. Лисицького [2]. Показники глобального суднобудування в першому кварталі 2019 р. аналізує М. Шевченко [3]. Роль контейнеризації для змішаних вантажних перевезень у розвитку світової торгівлі, у тому числі суднобудування, визначено у праці П.І. Підлісного [5], Н.О. Паткевич [5], Ю.В. Цвєтова [5]. Заслуговують на увагу міркування В. Федіна [6], чи стане суднобудування локомотивом економіки. Проте актуальним питанням суднобудування саме контейнерних суден належна увага не приділяється. Суднобудування, у тому числі, глобальне розглядається лише загалом. Такі зарубіжні автори, як: Б. Рольяно Саллес [6], М. Больман [7], Е. Крістенсен [8], Дж. Блейзер [8], Дж. Дрейк [8], Г. Кох [8], Дж. Лабовіц [8], Б. Немет та Н. Прінгл [8] досліджують питання розвитку морського транспорту та контейнерних перевезень більш детально, проте мало уваги приділено саме аспектам суднобудування, дані наводяться досить поверхнево. У статті використано авторитетні дослідження Clarksons [9; 10], Drewry
[11] про світове суднобудування, а також дані Ради $\mathrm{OOH}$ із питань торгівлі та розвитку (United Nations Conference on Trade and Development - UNCTAD) [12; 13] про світовий морський транспорт загалом та суднобудування зокрема.

\section{ВІДОКРЕМЛЕННЯ НЕ ВИРІШЕНИХ РАНІШЕ ЧАСТИН ЗАГАЛЬНОЇ ПРОБЛЕМИ}

Показники світового суднобудування привертають увагу багатьох дослідників, проте в наукових працях і публікаціях не розкрито стан, проблеми та перспективи саме контейнерного суднобудування, особливо не висвітлено питання суднобудівної галузі у сфері новітніх контейнерних суден. Потребує поглибленого дослідження формування висновків щодо стану, проблем та перспектив розвитку контейнерного суднобудування, оновлення світового флоту у світлі сучасних тенденцій.

\section{МЕТА ДОСЛІДЖЕННЯ}

Основним завданням цієї статті є дослідження стану, динаміки, проблем та перспектив контейнерного суднобудування у світі, визначення ролі оновлення флоту в забезпеченні контейнерних перевезень та розвитку глобальної морської торгівлі.

\section{МЕТОДИ, ОБ'ЄКТ ТА ПРЕДМЕТ ДОСЛІДЖЕННЯ}

Виконані розвідки грунтуються на застосуванні системного підходу, дедуктивного методу, порівняння, абстрагування, групування, методів економічного аналізу, узагальнення. Об'єктом дослідження виступає галузь суднобудування, предметом - сукупність теоретичних та практичних аспектів контейнерного суднобудування у світі.

\section{ОСНОВНИЙ МАТЕРІАЛ}

Пожвавлення світової економіки сприяє зростанню морської торгівлі, особливо контейнерних перевезень, що стимулює суднобудівну галузь. Взагалі слово «контейнер» походить від англійського to contain, що означає «містити», і представляє собою спеціальний засіб, пристосування для зберігання та перевезення будь-чого. У широкому значенні контейнер може мати різноманітні форми та види, може бути виготовлений із різних матеріалів, проте саме для потреб транспортування вантажів було прийнято стандарт для визначення розмірів контейнера, щоб використовувати його як універсальний засіб різними видами транспорту.

Перший контейнер, який почав успішно використовуватись у морському транспорті, був створений у 1956 р. М. Макліним. Він не був першим, хто створив контейнерне судно, але його, переобладнаний із нафтового танкера, контейнеровоз дав змогу суттєво збільшити швидкість не тільки транспортування, а й завантажувально-розвантажувальних робіт, що зменшило витрати і час простою судна в порту. Така ідея 


\section{СУДНОБУДУВАННЯ № 3- 2019}

мала успіх і наслідування. Тому у 1968 р. на міжнародному рівні було прийнято ISO 668 - перший стандарт, який визначив розміри транспортних контейнерів. Нині використовуються стандартні контейнери розміром 20 футів (6,09 м), 40 футів (12,18 м), 45 футів (14,6 м) і 53 фути (16,15 м) [15].

Найбільш поширеною еквівалентною одиницею $€$ TEU (Twenty-foot Equivalent Unit) - це стандартна міра, що відповідає об'єму двадцятифутового контейнера, використовується для обчислення місткості контейнеровозів та складів (місць зберігання контейнерів). Контейнери, побудовані за міжнародними стандартами, роблять їх взаємозамінними між судноплавними компаніями, залізничними і вантажними перевізниками. Також відомий ще більший тип контейнерів - FEU (Fourty-foot Equivalent Unit), що еквівалентний об'єму сорокафутового контейнера. Один сорокафутовий контейнер FEU дорівнює двом двадцятифутовим TEU.

За даними 2018 р., контейнеровози займають 23,5\% питомої ваги світового вантажного флоту. Зростання попиту на контейнеровози спостерігається ще 3 2014 р., особливо на судна великої місткості - понад 15000 TEU [12]. Світове лідерство в суднобудуванні традиційно зберігають Китай, Японія і Республіка Корея, яким у 2018 р. належить 90\% загального обсягу світового суднобудування. Лише на один Китай припадає 40\% суднобудівної промисловості світу, в той час як Японія і Республіка Корея володіють по 25\% відповідно [13]. Сфера суднобудування зазнає впливу реформ, консолідації та розвивається завдяки значній підтримці уряду. Екологічність та економічна ефективність завжди залишатимуться орієнтиром у суднобудуванні та стимулами в процесах модернізації морського транспорту.

За структурою суднобудівної галузі саме Китаю належить 49\% контейнерного суднобудування, 47\% загальної вантажопідйомності суден та $45 \%$ морських суден [13, с. 30-32]. Тому китайські верфі мають значний вплив на світові процеси суднобудування.

Новобудови контейнеровозів із розподілом за країнами будівництва та у співвідношенні з основними типами суден за підсумками 2018 р. представлено в таблиці 1. У структурі збудованих у 2018 р. суден найбільшу питому вагу від загального дедвейту зайняли балкери - 26,7\%, на другому місці нафтові танкери 3 $25 \%$, на третьому - контейнеровози з 23,5\%.

У 2018 р. було збудовано 13614 тис. валових т дедвейту, з яких 6630 тис. валових т, або 48,7\%, у Китаї, 3020 тис. валових т, або 22,2\%, в Японії, 2632 тис. валових т, або 19,3\%, у Республіці Корея, 992 тис. валових т, або 7,3\%, у Філіппінах і загалом 341 тис. валових т, або 2,5\% в інших країнах світу (рис. 1).

Таблиця 1. Суднобудування контейнерних суден у загальній структурі з розподілом за країнами будівництва у 2018 р., тис. валових т

\begin{tabular}{|c|c|c|c|c|c|c|c|c|}
\hline $\begin{array}{c}\text { № } \\
\text { 3.п. }\end{array}$ & $\begin{array}{c}\text { Типи суден, } \\
\text { тис. валових тонн }\end{array}$ & Китай & Японія & Філіппіни & Республіка Корея & $\begin{array}{c}\text { Решта } \\
\text { світу }\end{array}$ & Загалом & $\begin{array}{c}\text { Структура, } \\
\text { у \% }\end{array}$ \\
\hline 1 & Контейнерні судна & 6630 & 3020 & 992 & 2632 & 341 & 13614 & 23,5 \\
\hline 2 & У т.ч. за структурою, \% & 48,7 & 22,2 & 7,3 & 19,3 & 2,5 & 100,0 & х \\
\hline 3 & Танкери & 4505 & 2819 & 288 & 6046 & 865 & 14524 & 25,0 \\
\hline 4 & Балкери & 9274 & 5134 & 654 & 352 & 91 & 15505 & 26,7 \\
\hline 5 & Газовози & 762 & 1754 & 52 & 4709 & 26 & 7302 & 12,6 \\
\hline 6 & Інші & 2089 & 1713 & 2 & 894 & 2401 & 7100 & 12,2 \\
\hline 7 & Разом & 23260 & 14440 & 1988 & 14633 & 3724 & 58045 & 100,0 \\
\hline 8 & У т.ч. за структурою, \% & 40,1 & 24,8 & 3,4 & 25,2 & 6,4 & 100,0 & х \\
\hline
\end{tabular}

Джерело: складено за даними [13, с. 32; 19, с. 10]

Завершене суднобудування контейнерних суден, тис. валових т

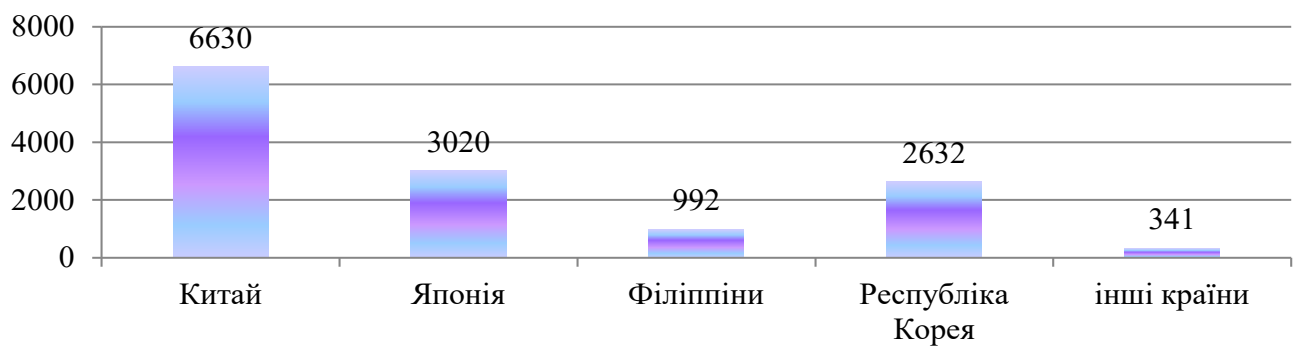

Рис. 1. Обсяг завершеного суднобудування контейнерних суден за країнами світу у 2018 р., тис. валових т

Джерело: складено за даними [13, с. 32; 19, с. 10] 
Загалом спостерігається тенденція до збільшення кількості контейнерних суден та скорочення балкерів і нафтових танкерів. Це пояснюється зростанням попиту на контейнеровози великої місткості - понад 15 000 TEU, суднобудування яких зросло на 33\% у 2018 p., та наявною надлишковою потужністю в інших видах суднобудування. Цей факт підкреслює також те, що в січні 2019 р. було зафіксовано суттєве скорочення кількості замовлень у галузі суднобудування, особливо на балкерні судна та нафтові танкери зменшення, відповідно, на 37\% та 48\% [16], проте замовлення на будівництво контейнерних суден зросло, особливо великої місткості і з сучасними двигунами на очищеному пальному відповідно до останніх вимог екологічного законодавства.

На початок 2019 р. загальний морський світовий вантажний флот становив 95402 судна місткістю понад 1979491 тис. дВТ (dwt) [13, с. 29]. Вантажопідйомність світового флоту зросла на 2,6\% порівняно 3 2018 р. Перевищення пропозиції в контейнерних морських перевезеннях стимулює збільшення місткості контейнерних суден та впливає на загальне зниження тарифів на фрахт. Тому в секторі контейнерних морських перевезень спостерігаються злиття, поглинання, консолідація та вертикальна інтеграція.

Потужність суден контейнерного флоту займає третє місце у вантажних морських перевезеннях. На першому місці з питомою вагою 42,6\% балкерні судна, 28,7\% - нафтові танкери, проте їхня динаміка зростання за даними на початок 2019 р. незначна 2,87\% та 0,98\% відповідно.

У 2018 р. потужність світового контейнерного флоту зросла на 6\%, що суттєво переважало динаміку збільшення обсягів морських контейнерних перевезень у $2,6 \%$ за цей період [13, с. 28]. За даними на початок 2019 р. за місткістю контейнерних суден світовий флот зріс як за показниками динаміки, так і за індикаторами структури. Так, у 2019 р. порівняно 32018 р. вантажопідйомність контейнерного флоту збільшилась на 4,89\% - від 253275 тис. дВТ (dwt) у 2018 р. 3 питомою вагою 13,1\% від загальної потужності світового флоту до 265668 тис. дВТ (dwt) у 2019 р. $з$ питомою вагою вже 13,4\% [13, с. 29]. Тому очікується, що в найближчій перспективі зростатиме напруга в морських контейнерних перевезеннях через монополізацію перевізників, збільшення місткості контейнеровозів, можливі економічні та політичні протистояння між США та Китаєм, а також через протекціоністські настрої, нові екологічні вимоги стосовно використання суднами очищеного палива, залежність від світового економічного розвитку і торгівлі.

Останні розробки в галузі суднобудування спрямовані на забезпечення основних аспектів стійкості (економічної, соціальної та екологічної) для галузі морського вантажного транспорту, досягнення екологічності у створенні, експлуатації та подальшої переробки суден, турботі про навколишнє природне середовище, зайнятість та економічну складову частину розвитку.

Нині середній вік суден, які передають в утилізацію/переробку, становить 21 рік [13]. Вік світового флоту має надзвичайно важливе значення для розвитку морських вантажних перевезень. Новіші судна більш ефективні, енергоощадливі, надійні, сучасно обладнані та комп'ютеризовані, де багато процесів мають автоматизований характер. Ризики зриву поставок чи екологічного забруднення навколишнього природного середовища для нових суден значно нижчі, тому дослідження вікового розподілу суден важливе для оцінки попиту в галузі суднобудування щодо потреб в оновленні флоту компаній-перевізників.

За даними за I квартал 2019 р., середній термін служби суден світового торгового флоту становить 21 рік [13, с. 28]. За сукупними середніми даними, $41,91 \%$ за кількістю світового торгового флоту становлять судна віком понад 20 років (таблиця 2) і $21,56 \%$ - судна віком від 5 до 9 років. Проте за показником вантажопідйомності найбільша питома вага в суден віком 5-9 років - 35,76\%.

Таблиця 2. Віковий розподіл світового флоту контейнерних суден за 2018-2019 рр.

\begin{tabular}{|c|c|c|c|c|c|c|c|c|}
\hline \multirow{2}{*}{$\begin{array}{l}\text { № } \\
\text { 3.I. }\end{array}$} & \multirow{2}{*}{ Показники } & \multicolumn{5}{|c|}{ Роки } & \multicolumn{2}{|c|}{ Середній вік, років } \\
\hline & & $0-4$ & $5-9$ & $10-14$ & 15-19 & $20+$ & y 2019 p. & y 2018 p. \\
\hline 1 & \multicolumn{8}{|c|}{ Контейнерні судна } \\
\hline 1 & Вікова структура за кількістю суден, \% & 16,68 & 21,77 & 31,32 & 13,95 & 16,28 & 12,34 & 11,89 \\
\hline 2 & Вікова структура за вантажопідйомністю (dwt), \% & 27,58 & 28,52 & 27,06 & 10,52 & 6,32 & 9,44 & 9,02 \\
\hline 3 & $\begin{array}{c}\text { Розподіл середньої вантажопідйомності } \\
\text { за віком суден (dwt) }\end{array}$ & 83362 & 66050 & 43565 & 38031 & 19579 & $\mathrm{x}$ & $\mathrm{x}$ \\
\hline 4 & \multicolumn{8}{|c|}{ Всі судна } \\
\hline 5 & Вікова структура за кількістю суден, \% & 12,72 & 21,56 & 15,29 & 8,53 & 41,91 & 20,98 & 20,48 \\
\hline 6 & Питома вага за вантажопідйомністю (dwt), \% & 23,76 & 35,76 & 19,73 & 10,76 & 9,99 & 10,44 & 10,06 \\
\hline 7 & $\begin{array}{c}\text { Розподіл середньої вантажопідйомності } \\
\text { за віком суден (dwt) }\end{array}$ & 44370 & 39985 & 30696 & 30946 & 6342 & $\mathrm{x}$ & $\mathrm{x}$ \\
\hline
\end{tabular}

Джерело: складено за даними [13, с. 31; 17] 


\section{СУДНОБУДУВАННЯ № 3- 2019}

Флот контейнерних суден оновлюється досить активно. Найбільшу питому вагу мають контейнерні судна віком 10-14 років - 31,32\%, за показником дедвейту - контейнеровози віком 5-9 років із питомою вагою 28,52\%. При цьому досить високий показник для новобудов віком до 4 років - 27,58\% за показником дедвейту та 16,68\% за кількістю збудованих контейнерних суден (рисунок 2).

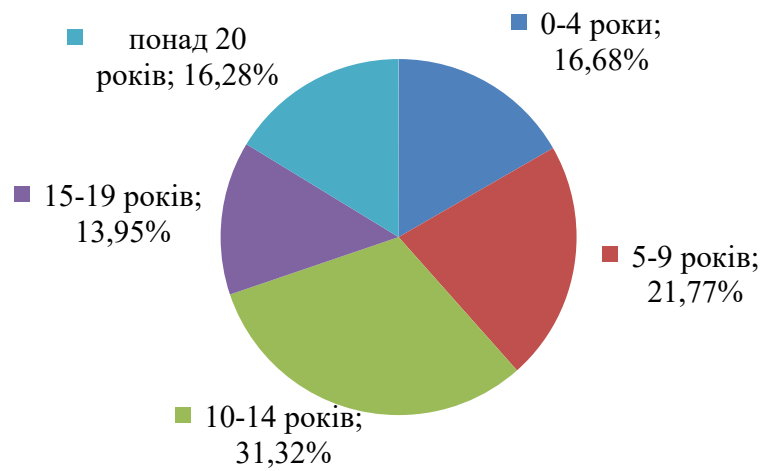

Рис. 2. Віковий розподіл світового флоту контейнерних суден у 2018 p. - початок 2019 p.

Джерело: складено за даними [13, с. 31; 17$]$

Можна стверджувати, що контейнерне суднобудування пожвавлюється, особливо в останні роки, що пов’язано з вимогою до їх більшої потужності, місткості, технічної оснащеності та екологічності.

3 набранням чинності регламенту IMO-2020 значна частина діючого флоту буде тимчасово виведена $з$ експлуатації для встановлення скруберів (фільтрів очистки палива), тому попит на новобудови зростатиме.

\section{ОБГОВОРЕННЯ ОТРИМАНИХ РЕЗУЛЬТАТІВ}

У світовому мореплавстві в економічних оглядах [6-11; 18; 19] мова йде про зростання потужності світового флоту. Після п'яти років повільного зростання у 2017 р. зафіксовано значне розширення світового флоту. Протягом 2017 р. до загального світового тоннажу було додано 42 млн валових тонн, що відповідає $3,3 \%$ темпів зростання [12, с. 20], у 2018 р. було введено 58 млн валових тонн дедвейту новобудов [13, с. 32], а у 2019 р. зростання завершеного суднобудування становило $2,6 \%$ [13, с. 29], що свідчить про активну участь морських перевезень у сфері транспорту в міжнародному масштабі.

Сектор суднобудування проходить складний період трансформації, що має забезпечити вимоги до конкурентоспроможності в умовах скорочення кількості замовлень та фінансування. В азіатських країнах уряд проводить низку заходів для підтримки галузі суднобудування. Так, Республіка Корея вже у 2018 р. надала державні субсидії на виробництво суднових двигунів і морського обладнання, що впливає на цінову політику і конкуренцію в галузі. Деякі європейські країни закликають до розширеної під- тримки уряду з забезпеченням податкових пільг до 2050 р. [17]. У галузі суднобудування спостерігається тенденція до об'єднання найбільших суднобудівних компаній, зокрема в Китаї планується злиття китайської державної суднобудівної корпорації (China State Shipbuilding Corporation) та китайської корпорації суднобудівної промисловості (China Shipbuilding Industry Corporation) [18].

У сфері суднобудування сучасними тенденціями $\epsilon$ врахування вимог ринку і екологічного законодавства. Отже, проектування та будівництво суден має відповідати новим стандартам безпеки, енергозбереження та екологічності щодо викидів і споживання очищеного палива 3 мінімальним вмістом сірки та викидів вуглецю. Також значні інвестиції спрямовані на дослідження і розробку кращої гідродинаміки. Так, компанія Maersk інвестує близько 1 млрд доларів США щороку на інновації та розвиток технологій у галузі суднобудування [17]. Зокрема, розробки спрямовані на подальшу цифровізацію, розширення мережі Інтернет, застосування штучного інтелекту та блокчейн [18]. Також посилюється акцент на екологічність нових суден, значного розвитку набувають тенденції добровільної екологічної оцінки суден. Відомі такі показники, як Індекс чистої доставки (Clean Shipping Index), Індекс екологічності судна (Environmental Ship Index), Зелена премія (Green Award), Рівень ефективності управління енергозбереженням судна (Ship Energy Efficiency Management Plan) [19]. Суднобудівні країни, для яких цей сектор має загальнодержавне значення, також прагнуть відповідати сучасним тенденціям, щоб і надалі залишатись конкурентоспроможними.

\section{ВИСНОВКИ}

Як показують дослідження, у 2019 р. світовий торговий флот налічує 95402 суден із 1976491 тис. дедвейту (dwt), з яких 13,4\% становлять контейнеровози. При цьому Китаю належить $49 \%$ контейнерних суден у світі.

Світове суднобудування має ряд особливостей, пов'язаних із використанням значних ресурсів: матеріальних, фінансових, трудових, часових. Це фондоємна, науково та інноваційно містка галузь. У сфері контейнерного суднобудування спостерігаються тенденції до будівництва суден великої місткості, сучасно технічно оснащених, які відповідають більш жорстким екологічним стандартам, при цьому інновації та розробки спрямовані на забезпечення ощадливого споживання енергоресурсів, цифровізації процесів, застосування штучного інтелекту, блокчейн. Проблемами останніх років у галузі контейнерного суднобудування є диспропорція між коливаннями економіки, світової торгівлі та пропозицією флоту, й відповідно обсягами замовлень у суднобудівних компаніях. Крім того, спостерігається дисбаланс за географічним роз- 
ташуванням суднобудівних потужностей та рівнем розвитку національних економік, що впливає на будівництво й експлуатацію флоту контейнерних суден.

Перспективами подальших досліджень є визначення новітніх тенденцій у галузі суднобудування, впровадження інновацій, енергозберігаючих та екологічно безпечних технологій, інформатизації транспортних процесів. У сфері реалізації морських контейнерних перевезень актуальним напрямом дослідження є вивчення інтеграції морського, залізничного та автомобільного транспорту в контрейлерних перевезеннях.

\section{REFERENCES}

[1] Diordiev, V. O. (2018). Problemy ta perspektyvy sudnobudivnoyi haluzi Ukrayiny u hlobal'nomu konteksti [The Problems and Prospects of Ukraine's Shipbuilding Industry in a Global Context]. Effective Economy, vol. 10. Retrieved from: http:// www.economy.nayka.com.ua/pdf/10_2018/155.pdf [in Ukrainian].

[2] Lysytsky, V. (2013). Sudostroyeniye Ukrainy - ot upadka k vozrozhdeniyu [Shipbuilding of Ukraine - from Decline to Revival]. Segodnya. Retrieved from: http://www.segodnya.ua/blogs/lisickiyblog/blog-sudostroenie-ukrainy-ot-upadka-kvozrozhdeniyu-484682.html [in Ukrainian].

[3] Shevchenko, M. (2019). Hlobal'ne sudnobuduvannya u pershomu kvartali 2019 r. [Global Shipbuilding in the First Quarter of 2019]. Porty Ukrayiny, publication Date 8th May. Retrieved from: https://ports.com.ua/articles/globalnoe-sudostroenie-vpervom-kvartale [in Ukrainian].

[4] Pidlisny, P. I., Patkevich, N. O., Tsvetov, Yu. V. (2016). Rol' konteyneryzatsiyi zmishanykh vantazhnykh perevezen' u rozvytku svitovoyi torhivli [The role of containerized cargo transportation in the development of world trade]. Ekonomichnyy forum, vol. 3, pp. 67-81. [in Ukrainian].

[5] Fedin, V. (2018). Chy stane sudnobuduvannya lokomotyvom ekonomiky [Will shipbuilding become the engine of the economy]. Business, published 8th May. Retrieved from: https://nv.ua/en/biz/experts/chi-stane-sudnobuduvannyalokomotivom-ekonomiki-2468574.html [in Ukrainian].

[6] Barry, Rogliano Salles (2018). Annual review 2018: Shipping and shipbuilding markets. Retrieved from: https://it4v7. interactiv-doc.fr/html/brsgroup2018annualreview_pdf_668 [in France].

[7] Bohlman, Michael (September 2001). ISO's container standards are nothing but good news. ISO Bulletin (International Organization for Standardization) [in EU].

[8] Christensen, E., Blaeser, J., Drake, J., Koch, G., Labovitz, J., Nemeth, B., Pringle, H. (2019). Global container shipping outlook: IMO 2020 weighs on an industry struggling to generate sustained profitability, Alix Partners, 19 February [in EU].

[9] Clarksons Research (2019), “Container Intelligence Monthly”, Volume 21, May [in UK, China].

[10] Clarkson PLC (2018). Clarkson PLC today announces unaudited interim results for the six months ended 30 June 2018. Retrieved from: https://www.clarksons.com/media/1144157/interim_results_announcement_2018.pdf [in UK].

[11] Drewry Maritime Research (2019). Container Forecaster, Quarter 2, June [in UK].

[12] UNCTAD (2018). Review of Maritime Transport 2018. United Nations publication, Sales No. E.18.II.D.5, New York and Geneva, ISSN 0566-7682 [in USA, Switzerland].

[13] UNCTAD (2019). Review of Maritime Transport 2019. United Nations publication, Sales No. E.19.II.D.20, New York and Geneva, ISSN 0566-7682 [in USA, Switzerland].

[14] Global Environment Facility, United Nations Development Programme, IMO Global Maritime Energy Efficiency Partnerships Project and International Association of Ports and Harbours (2018). Port Emissions Toolkit: Guide, No. 1, Assessment of Port Emissions. Elephant Print. Lewes, East Sussex [in USA, UK, EU, Switzerland].

[15] Allianz Global Corporate and Specialty (2017). Safety and Shipping Review 2017, Munich [in Germany].

[16] IHS Markit (2019). Shipping and Shipbuilding Outlook, March [in UK].

[17] International Chamber of Shipping (2019). Shipping Industry Flag State Performance. Table: 2018/2019. London [in UK].

[18] Universal Cargo (2019). Two big problems ocean freight shipping faces in 2019, 31 January [in USA].

[19] Maritime ports freight and passenger statistics (2019). Statistics Explained, May 2019, 17 p. Retrieved from: https:// ec.europa.eu/eurostat/statistics-explained/pdfscache/6652.pdf [in EU].

\section{СПИСОК ВИКОРИСТАНОЇ ЛІТЕРАТУРИ}

[1] Діордієв, В. О. (2018). Проблеми та перспективи суднобудівної галузі України у глобальному контексті. Ефективна економіка. 2018. № 10. URL: http://www.economy.nayka.com.ua/pdf/10_2018/155.pdf

[2] Лисицкий, В. (2013). Судостроение Украины - от упадка к возрождению. Сегодня. URL: http://www.segodnya.ua/ blogs/lisickiyblog/blog-sudostroenie-ukrainy-ot-upadka-kvozrozhdeniyu-484682.html

[3] Шевченко, М. (2019). Глобальне суднобудування у першому кварталі 2019 р. Порти України. Дата публікації 8 травня 2019 p. URL: https://ports.com.ua/articles/globalnoe-sudostroenie-v-pervom-kvartale

[4] Підлісний, П. І., Паткевич, Н. О., Цвєтов, Ю. В. (2016). Роль контейнеризації змішаних вантажних перевезень у розвитку світової торгівлі. Економічний форум. № 3. С. 67-81.

[5] Федін, В. (2018). Чи стане суднобудування локомотивом економіки. Бізнес. Дата публікації 08 травня 2018 p. URL: https://nv.ua/ukr/biz/experts/chi-stane-sudnobuduvannya-lokomotivom-ekonomiki-2468574.html 


\section{СУДНОБУДУВАННЯ № 3- 2019}

[6] Barry Rogliano Salles (2018). Annual review 2018: Shipping and shipbuilding markets. Available at https://it4v7.interactivdoc.fr/html/brsgroup2018annualreview_pdf_668.Allianz Global Corporate and Specialty (2017). Safety and Shipping Review 2017. Munich.

[7] Bohlman, Michael (September 2001). ISO's container standards are nothing but good news. ISO Bulletin (International Organization for Standardization).

[8] Christensen, E. Blaeser, J. Drake, J. Koch, G. Labovitz, J. Nemeth, B. Pringle, H. (2019). Global container shipping outlook: IMO 2020 weighs on an industry struggling to generate sustained profitability. Alix Partners. 19 February.

[9] Clarksons Research (2019). Container Intelligence Monthly. Volume 21, May.

[10] Clarkson (2018). PLC today announces unaudited interim results for the six months ended 30 June 2018. URL: https://www. clarksons.com/media/1144157/interim_results_announcement_2018.pdf.

[11] Drewry Maritime Research (2019). Container Forecaster. Quarter 2. June.

[12] UNCTAD (2018). Review of Maritime Transport 2018 (United Nations publication. Sales No. E.18.II.D.5, New York and Geneva) ISSN 0566-7682.

[13] UNCTAD (2019). Review of Maritime Transport 2019 (United Nations publication. Sales No. E.19.II.D.20, New York and Geneva) ISSN 0566-7682. https://unctad.org/en/PublicationsLibrary/rmt2019_en.pdf

[14] Global Environment Facility, United Nations Development Programme, IMO Global Maritime Energy Efficiency Partnerships Project and International Association of Ports and Harbours (2018). Port Emissions Toolkit: Guide No. 1 - Assessment of Port Emissions. Elephant Print. Lewes, East Sussex.

[15] Allianz Global Corporate and Specialty (2017). "Safety and Shipping Review 2017”, Munich.

[16] IHS Markit (2019). Shipping and Shipbuilding Outlook. March.

[17] International Chamber of Shipping (2019). Shipping Industry Flag State Performance Table: 2018/2019. London.

[18] Universal Cargo (2019). Two big problems ocean freight shipping faces in 2019. 31 January.

[19] Maritime ports freight and passenger statistics (2019). Statistics Explained, May 2019, 17 p. URL: https://ec.europa.eu/ eurostat/statistics-explained/pdfscache/6652.pdf. 